\title{
VALUE ISSUES IN RELIGIOUS EDUCATION
}

\author{
Hacer ÂŞIK EV*
}

\begin{abstract}
The valuations that have a potential to diffuse almost in every area of individual and social life are not static but rather may be transformed due to development and change. The religious education as a part of formal and public education and often determined by high values and occasionally by mediator values should keep abreast of the change and transformation of modern era from different aspects, because religious education has an active role in the adaptation process of a community to the changes in its environment via socialization.

Therefore more importance should be given to religious education and it should be in cooperation with other human sciences. Religious education that should serve under the light of experimental data should constantly renew itself by considering life, life values and expectancies.

Thus, such a religious education is able to provide awareness to an individual freedom and critical point of view, reflect religious information, help in understanding traditions, re-create people and activities and make contributions to transformation of the social and general world.
\end{abstract}

Keywords: Religious education, values, transformation and change, critism.

*Ph.D., hacerev@hotmail.com 


\section{SUMMARY}

The values that have an active role in determination of human opinion, attitude, achievement, life and etc. are not static. They may be modified in parallel to scientific, technical, economical, political, social etc changes. When the dynamic flow in different areas of culture is not taken into consideration, these circumstances reckon without and some problems may appear due to the bound translation and transformation of these values. Because, the situation whether a society has a fluent or a dull progress , penetration of a philosophy into a society, the functioning of an education system, and forming the individuals and society all depend on determination of values.

In this study, different opinions related to the possibility of religious education (which is often determined by high values and occasionally by mediator values) as a part of public and formal education were provided. The aims, contents and methods will be debated in view of the values belonging to modern world.

The opinions regarding the possibility of religious education may be classified into 3 groups: a secular society should be objective against different religious beliefs; it is possible to understand religion but not to give its education; religious education should be incorporated within the curriculum.

Paulo Freire suggests that education should an instrument of transformation as an application serving the continuous human freedom. Is religious education in the service of human freedom and is a medium of the transformation phenomenon? Or which goals should religious education possess in order to realize the transformation and guide the individual to free, critical, creative thought, emotion and behaviour?

First, "religious nurture", "religious research" and "religious education" should be differentiated. Religious education becomes a problem when complicated with religious nurture and belief inculcation because their purposes are different and include utilization of non-rational methods and harbor familiarization of principles rather than providing knowledge and evaluating.

The noticeable question of religious education is "What is religious education related to? What should be given as "religion" to the receivers? Does the offered content of the religious education meet the demand and requirement of the receivers? Is this content appropriate for the cognitive, emotional, psychomotor and cultural developmental level of the receivers? Is the religious education program oriented toward the development of the potential forces of receivers? Or is it full of out of life, disconnected, non- 
dynamic information? Or is religion used as a means of pressure in order to create weak people? In other words, is the self-confidence and thereby liberalism of the individuals being restrained ?

The answer to the question "What should religious education be related to ?" is "more than transferring a legacy of a particular religion". It is learning, it is life and a development that should be in association with constantly developing societies till it encompasses all the world.

The change in objective of religion has also caused changes in its methodology. The insight of the sacred text and understanding of its message are considered to be more significant than learning the events that have passed. For the purpose of realization of the necessity of a religious education that will be meaningful to the students, several studies were instituted concerning the novel aims, contents and methods.

The dynamic understanding is replaced by giving traditional information and memorization of the sacred texts. The "mütekaddimin" period which is before the Ottomans in which unlimited freedom of opinion and critism were present, has attracted attention with creative thoughts and scientific life which yielded important works. In case when science is considered only as a knowledge transfer dissident thoughts, productive mind is replaced by passive, non-questioner, non-creative minds and therefore development and progression were impeded.

As a result, through socialization which has two important objectives such as protecting the identity and existence of a community and provide life to the next generation, a community tries to maintain its existence and adapt to the surrounding changes. Religious education has an active role in this process. Therefore, the religious education sciences (religion pedagogy) should gain more attention in our country and this field should be in association with other human sciences. This science should serve under experimental research data and renovate itself considering life, life values and expectations.

Attachment to religious views doesn't mean to be closed to alternative beliefs or others' beliefs and avoiding the necessities of the modern world. Likewise, open mindedness and neutrality are not equal to atheism. Dependence on a belief should not prevent one to be open minded. In other words, dependence on a belief should not be an obstacle in understanding other beliefs and respect them. Actual transformation and change do not eliminate values during this effort and continuously reorganize them.

Religious education providing liberal and critical awareness to people is expected to reflect religious knowledge, help in understanding of traditions, re-create individual beliefs, values and activities and contribute to social and general topics of the changing world. 


\title{
DİN ÖĞRETIMINDE DEĞERLER SORUNU
}

\author{
Hacer ÂȘIK EV*
}

ÖZ. Birey ve toplum hayatının hemen hemen her alanına yayılabilen değerler statik değildir, gelişim ve değişimden etkilenerek dönüşüme uğrayabilmektedir. Çoğu zaman yüksek değerler zaman zaman da aracı değerler tarafindan belirlenen, yaygın ve örgün eğitimin bir parçası olan din öğretimi de çeşitli açılardan modern çağın değişim ve dönüşümüne ayak uydurmak durumundadır. Çünkü toplumun sosyalizasyon aracılı̆̆ ile varlığını devam ettirme ve çevresindeki değişikliklere uyum sağlama çaba ve sürecinde din öğretimi aktif bir rol üstlenir.

$\mathrm{Bu}$ nedenle din öğretimine ülkemizde önem verilmeli ve bu alanın diğer insan bilimleriyle işbirliği içinde olmasına dikkat edilmelidir. Diğer insan bilimlerinin verilerinden yararlanan din öğretimi yaşamı, yaşamsal değerleri ve beklentileri hesaba katarak kendini sürekli yenilemelidir. Çünkü din insan içindir, bu da dinin ve onun öğretiminin bilimsel, teknik, sosyal, vs. gelişme ve değişmelerin 1şığında iş görmesini gerektirmektedir.

Ancak böyle bir din öğretimi bireyin özgür ve eleştirel bir şekilde kendinin ve çevresindekilerin farkında olmasını sağlayarak, din ile ilgili bilgiyi yansitabilir, geleneğin anlaşılmasına yardımcı olabilir, bireysel inançları, değerleri ve eylemleri yeniden yaratarak, sosyal ve genel dünyay1 dönüştürme konularında katkıda bulunabilir.

Anahtar Kelimeler: Din öğretimi, değerler, dönüşüm ve değişim, eleştirel düşünce.

*Ph.D., hacerev@ hotmail.com 


\section{GİRIŞ}

Ontoloji bakımından "var olan" bir alan oluşturan insanın bütün hareket ve eylemleri, her real varlık alanı gibi bir varlık alanıdır ve bu alanı belirleyen ilkelere "değerler" adı verilir. (Mengüssoğlu, 1968, 192). Hayatına, başarılarına şekil verme, onun yaptıklarını belirleme gibi insanın belirlenim sorununda aktif rol oynayan değerler yüksek ve aracı değerler olmak üzere ikiye ayrılır. Çok geniş bir alana yayılan değerlerden idealler, inançlar, dürüstlük, adalet, sevgi ve sayg1 gibi değerler yüksek değerler; yarar, ilgi, çıkar, tutkular, kuvvet ve iktidar faktörleri, mevki ve şeref hırsı, vb. değerler de aracı değerler çerçevesi içine yerleştirilebilir. (Mengüşoğlu, 1968, 192). Her iki değerler tarafından belirlenen insan eylemleri ve bunların ürünleri, çoğunluğunun hayatı ilgi ve çıkar alanına ait olduğundan, daha çok aracı değerler tarafindan belirlense de, ilim ve sanat alanına ait eserleri belirleyen aracı değerler değil, yüksek değerlerdir (Mengüşoğlu, 1968).

Değerler statik değildir, bilimsel, teknik, ekonomik, siyasi, bireysel, toplumsal, vb. alanlardaki değişikliklere paralel olarak değişim ve dönüşüme uğrayabilir. Örneğin bir bilgi toplumunun bireysel ve toplumsal değerleri bir tarım toplumununkinden farklıdır; yine modern bir toplumun sahip olduğu değerler ile geleneksel kültürün egemen olduğu bir toplumun değerleri aynı değildir. Daha somut bir örnek vermek gerekirse geleneksel toplumun kadına yaklaşımı, bu toplumdaki kadının konumu ile modern toplumdaki kadının değeri ve konumunun belirleyicisi olan değerlerin aynı olduğunu söylemek mümkün değildir. Kültürün farklı alanlarındaki hareketlilik, dinamik akış dikkate alınmadığında; değerlerin bağlı olduğu ve beslendiği söz konusu olan bilimsel, teknik, ekonomik, siyasi, bireysel, toplumsal, vb. alanlardaki gelişmelerin yanında doğru bilgi, inanç, etik, felsefe ve sanattaki gelişmeler, değişiklikler göz ardı edilerek değerlerin gelişim, değişim ve dönüşümü engellendiğinde veya gerçekleşemediğinde çeşitli sorunlar ortaya çıkabilir. Çünkü bir geleneğin akıcı veya donmuş bir şekilde devamı; bir felsefenin toplumu etki altına alması; bir eğitim sisteminin işleyiş̧i, bireyleri ve toplumu şekillendirmesi hepsi değer belirlenimine dayanır (Mengüşoğlu, 1968). Bu makalede, çoğu zaman yüksek değerler zaman zaman da aracı değerler tarafindan belirlenen, yaygın ve örgün eğitimin bir parçası olan din öğretiminin öncelikle imkânı konusundaki farklı görüşlere yer verilerek, amaçlar, içerik ve yöntemi modern çağın değerleri açısından ele alınmaya çalışlacaktır.

Burada "din öğretimi” kavramından kastedilen "din hakkında öğretmek”tir, "dinî yetiştirme" değildir. Öğretim eyleminde uyandırma, farkına vardırma, bilinçlendirme, bakış açısı ve hayat anlayışı dönüşümü süreçleri yaşandığından din öğretimi de doğası itibari ile kendimizin ve 
bizim dışımızda olanların eleştirel bir farkına varma sürecini, uyandırmayı, bilinçlendirmeyi, hayatın anlamı konusunda bakış açısı dönüşümünü kapsar. (Daha geniş bilgi için bkz., Orta Öğretim Din Kültürü Ve Ahlâk Bilgisi Dersi Öğretim Programı, Milli Eğitim Bakanlığı, 2005; Din Öğretiminde Yeni Yaklaşımlar, Milli Eğitim Basımevi, 2000) Kendimizin ve ilişkilerimizin psiko-kültürel yapısı içinde eleştirel bir farkına varma süreci veya pratiği olan "bakış açısı dönüşümü”, referansların yeniden yapılanmış çerçevelerine ve hayatın içinde olan yeni bir teorinin gelişimine izin verir (Schipani, tarihi yok, 19).

Din öğretiminden hangi tür anlama ve bilgi türetilebilir? Din öğretimi diğer alanların öğretiminden ilke olarak farklı mıdır? Din okul müfredatlarında yer almalı mı? $\mathrm{Bu}$ ve benzeri sorular nin öğretiminin temellerini, amacını, içeriğini, ilke ve yöntemlerini belirlemede yardımcı olur.

\section{A. DINE EĞITTIM PROGRAMI İÇERÍSINDE YER VERILLBİLÍR Mİ?}

Din öğretiminin imkânı konusundaki görüşleri seküler bir devletin farklı dinî inançlar karşısında tarafsız kalması gerektiği; dini anlamanın mümkün olduğu, fakat öğretiminin mümkün olmadığı ve din öğretiminin okul programlarında yer alması gerektiği ile ilgili olmak üzere üç grupta sinıflandırmak mümkündür.

Birinci grupta yer alan görüşe göre, din öğretimi öğretim programında yer almamalıdır. Çünkü farklı dinî inançlara karşı tarafsız kalınması gereken günümüz seküler toplumunda birleşen çeşitli faktörler, dinî inançların doğruluğu konusunda şüpheyi ürettiğinden, bilimin önermeleri kanıta başvurulacak gerçekler olarak kabul edilirken, dinin iddialarının böyle değildir (Iheoma, 1997). Sekülarist yaklaşımda belli bir dinin öğretiminden çok, bütün dinlere eşit uzaklıkta durularak, özellikle toplumda yaşanan dinlerin öğretimi yapılabilir, dolayısıyla din öğretiminin eğitsel amaçları da başkasını kendi dinine çekmek veya mezhepsel ilgilerden farklıdır. $\mathrm{Bu}$ yaklaşımda din konusunda savunmacı, taraftar olmaktan çok açıklayıcı olunmalı, dindar olmayı öğretmekten çok din hakkında bilgilendirmelidir, çünkü fikir aşılamaktan kaçınmak ahlakî bir sorumluluktur (Iheoma, 1997).

Dinin öğretim programında yer almaması gerektiğini savunanlardan bazılarının da gerekçesi dinlerin, özellikle İslâm dininin akla ve özgür düşünceye yer vermediği ve her tür gelişmeyi engellediği iddiasıdır.(Ayhan, 1998). 
Sekülarist yaklaşımdaki "dinin iddialarının bilimin önermeleri gibi gözleme, deneye, vs. başvurularak doğru olup olmadığı test edilebilecek gerçekler olarak kabul edilemeyeceği ile ilgili varsayım"a şu şekilde bir itiraz vardır: Deneysel olarak doğrulanabilen bilginin yayılması ile ilgili olmayan yalnızca din öğretimi değildir, öğretim programlarında yer alan başka birçok konular da önerme bilgilerini veya deney ile doğrulanabilen bilgiyi vermez (Iheoma, 1997). Örneğin, bazı matematik ve tarih önermeleri de deney ile doğrulanabilen bilgiyi vermemektedir. Ayrıca dünün deney ile doğrulanabilen bilgileri, doğruları bugünün bilimsel gelişmelerin 1şığında yanlışlanabilmektedir ve bugünün doğrularının gelecekte de yanlışlanabilme olasılığının bulunduğu söylenebilir.

Din öğretiminin öğretim programında yer alıp almaması ile ilgili ikinci görüş, din öğretilemez ancak din hakkında bilgilendirilebilir. Dinin öğretilemeyeceğini fakat din hakkında öğretilebileceğini savunan Hirst'e göre, din öğretimi herhangi bir doğruya bağl1lığı değil, yalnızca dinî inançları öğretmeyi içerir. Sealey'e göre ise, eğitim yaşantıya sahip olmaktan daha çok yaşantının araştırılması, çalışılması ile ilgili ikinci düzeyden bir eylemdir ve din öğretimi de böyledir (Akt. Iheoma, 1997: 33, 34). Bu ikinci grupta yer alan görüşe göre, dini anlamak mümkündür, fakat bu din öğretiminin mümkün olduğu sonucunu çıkartmaz. Dinî inançlar rasyonalitenin evrensel ölçütleri ile tam olarak uyuşmadığından, çocuklara dini öğretme eğitim amaçları ile açıkça çatışan inançları aşılama anlamına gelir, bu dini aş1lamadır, eğitim değildir (Iheoma, 1997).

Din öğretiminin mümkün olduğunu savunan üçüncü grupta yer alan görüşe göre ise, eğer eğitim anlamanın çeşitli formlarına öğrenciyi yöneltmekse din öğretimi de programın yasal bir parçası olmalıdır, çünkü ilke olarak dini anlamak da herhangi bir alanı anlama süreci gibidir ve din de tecrübenin özel bir çeşidinin anlaşılmasından oluşur (Iheoma, 1997). Ayrıca dünyanın eleştirel yorumunun sadece okul dışında yapılması yeterli değildir, okul programlarında yer alacak olan din dersi bu eğitimin verilebileceği en uygun zemindir (Kirste, 2003: 124). Din öğretimi öğrenciyi dünyanın eleştirel bir yorumuna, dinî düşünceye, bir çeşit açıklamaya ve yaşantının bir formuna alı̧stırmak için bir girişimi kapsar. Din öğretimi hem bir bilgilendirme aracı hem de bilgi elde etme yollarını ve aklını kullanma yeteneğini geliştiren bir süreç olmalıdır. Öğrenciler kendilerine sunulan alternatifleri inceleyebilmek için din hakkında doğru bilgilendirilmeye, bilinçlendirilmeye ve bakış açılarının geliştirilmesine ihtiyaç duyarlar. Onlar bilginin hangi amaçla, kim için, nasıl bir dünyada kullanılabileceğini sorgulayacak biçimde yetiştirilmelidir. $\mathrm{Bu}$ da dini metinleri ezberleterek, ilmihal bilgilerini belleterek gerçekleştirilemez. (Orta Öğretim Din Kültürü 
Ve Ahlâk Bilgisi Dersi Öğretim Programı) Öğrencilere sorgulayııı ve eleştirel bir tutum kazandırmanın yollarından biri, onların soru sormalarına fırsat verme, yüreklendirme ve teşvik etmektir; onların soru sormaları dini kavramlar ve dini metinler ulaşılamaz uzaklıklara konularak ve bir tabu haline getirilerek engellenmemelidir. Bu konuda dikkat edilmesi gereken önemli bir nokta, öğrenenlerin her türlü sorularına bıkmadan, sorular atlanmadan sabırla, açıklıkla cevap verilmesidir. Ayrıca dini bir ilke öğretim konusu yapıldığında, örneğin, bir yardımlaşma konusu ele alınırken, önce kavram analizinden başlanmalı, yardımlaşmanın ne anlama geldiği, bireysel, toplumsal ve diğer açılardan öneminin neler olabileceği üzerinde düşündürülmeli, daha sonra niçin bu ilkenin yer aldığı, bunun ile ne amaçlandığı, bu ilke işletilirse kazanımların neler olacağı, işletilmesi bireysel, toplumsal, vb. açılardan kayıpların neler olabileceği üzerinde düşündürülmeli ve eleştirel bir yaklaşımla sorgulamaları için cesaretlendirilmelidir. Duyuları doğru kullanma, baktığını görebilme, betimleme, doğru bilgiye ulaşma yollarını öğretme, gördüklerinden ders çıkartma, düşünme, araştırma, aklını kullanma, sorgulama, karşılaştırma, taklitten sakınma, objektiflik, analiz ve sentez gibi tutumları edindirerek öğrencinin eleştirel ve sorgulayıcı bir yaklaşıma sahip olmasına yardım edilebilir.

W. D. Hudson deneyim tarafindan türetilen önerme ile ilgili olan "bilmek-knowledge" ile belli bir deneyimden kaynaklanma olasılığı olan "anlamak-understanding" kavramlarını birbirinden ayırır. Birinci görüş, "knowledge that - bir şeyi bilmek"; ikincisi, "knowledge how - bir şeyin nasıl yapılacağını bilmektir", bu anlama ile ilgilidir, "anlamak"tan kastedilen de "nasıl olduğunu bilme"dir (Akt. Iheoma, 1997: 30, 32). Okullardaki formal eğitim çeşitli konularda öğrenciye düşünme ve akıl yürütmeyi öğretmek için "nasıl olduğunu bilme”yi öğretme çabasıdır, din öğretimi de öğrencileri dini ayırt edici kavramlar veya kategorik kavramlarında düşünmeye ve anlamlı konuşmaya alıştırdığından "nasıl olduğunu bilme" çabası içinde yer alır (Iheoma, 1997).

Birçok liberal filozofa göre eğitim rasyonel olmayı öğrenmektir. Din öğretiminin imkânını savunanlar tarafından da dinî inançlar ve dinî deneyimin belli bir anlama ve bilgi çeşidini bildirmek için düzenlenen rasyonel bir girişim olduğu kabul edilir (Iheoma, 1997). Emler Thiessen dinî inançların toplumda oldukça rasyonel diye kabul edilen insanlar tarafından da kabul edildiğine dikkat çeker (Akt. Iheoma, 1997: 27). W. D. Hudsan da dinî inançların ve kavramların anlaşılmasının rasyonel gelenek içinde yer alan eğitimsel aktivite ile uyumlu olduğunu ileri sürer (Akt. Iheoma, 1997: 3). 
Ayrıca din öğretiminin pozitif tutumları geliştirmeye yardımcı olabileceği de iddia edilir. Böyle bir eğitim bir taraftan bireyi ümitsizlik, kayg1, şüphe ve her türlü korkuya karş1 güçlü kılarken, öte yandan ona varlıkla ilișki kurabilecek yeni motivasyonlar sağlayıp, olay ve olguları anlamlandırmaya yardım ederek bireyi zorlukların üstesinden gelmeye donanımlı kılar ve aynı zamanda insana, düşünceye, özgürlüğe, ahlâkî olana ve kültürel mirasa saygıyı da geliştirir. (Selçuk, !997: 151-156). Dinde yer alan sevgi, yardımlaşma, dayanışma, düşmanlık beslememe vb. ahlakî ilkeler bireyi kötülüklerden sakındırarak iyiliğe yönelmeye de motive edebilir.

Din öğretiminin okullarda öğretilebileceği görüşünü ileri sürenlerin yanı sıra din öğretiminin gerekliliğini savunan Bilgin'e göre ise, "Okulun görevi, toplumun çok amaçlı özelliğini hiçe saymak, onu görmezlikten gelmek veya ideolojik olarak yıpratmak gibi uygulamalarla bağdaşamaz. Okul, dini bir tavır da takınamaz, buna yetkili değildir. Çok amaçlı toplumun okuluna uygun olan, ideolojik bir öğretim amacı değil, fakat öğrencilerin, gerçeğin bütünü ile karşılaşmasını hedef alıcı bir öğretimdir. Bu bütünlük içinde okul öğrencilere, İslâm dininin getirdiği dünya görüşünün temel ilkelerini tanıtmak, onlara gerçeğin dini açıdan nasıl yorumlandığı konusunda da bilgi vermek durumundadır. Okul, din ile ilgili sorular yokmuş gibi davranamaz, onları kendiliğinden veya başka branşlar yolu ile de cevaplandıramaz. Toplum politikası açısından din dersi, okulda, dinin toplum içinde sahip olduğu yere uygun bir biçimde temsil edilmek durumundadır (Bilgin, 2001, 67-68). Görüldüğü gibi din öğretiminin imkânı konusundaki birinci görüş, din öğretimi mümkündür, ikinci görüş ise din öğretimi gereklidir görüşüdür.

Din öğretiminin modern toplumların çoğulcu karakteristiğinden dolayı da gerekli olduğu düşünülebilir. Çünkü dünyada çeşitli sebeplerden dolayı dinamik bir şekilde farklı iklim ve kültürler arası göç hareketleri gözlenmektedir, çoğunlukla bozulmamış kültürleri ile göç eden bu insanların göç alan yerleşim bölgesindeki yaşayanlar ile ilişkilerini saygı ve hoşgörü temeline dayandırabilmeleri birbirlerini daha iyi tanımalarına bağlıdır. Kültürün bir parçası olan farklı dinlere öğretim programında yer verilerek buna katk1 sağlanabilir. Dini çoğulculuğun dışındaki hiçbir tecrübe, insanların varsayımlarını ve inançlarını, aynı zamanda ibadet şekillerini, diğer inançların mensupları ile komşu olarak yaşama ve günlük hayatla ilgili konularda onlarla iletişim kurma girişiminde bulunmayı gözden geçirmeye imkân veremez (Thompson, 1988).

Öğretim programında farklı dinlerin yanı sıra aynı dinin farklı yorumlarına da yer verilerek toplumdaki çekişmelerin, kutuplaşmaların önüne geçilebilir ve farklı kültüre ve yoruma sahip olanlar egemen anlayış tarafından ötekileştirilmeden empati geliştirilerek en azından tolerans 
temeline dayanan diyalog kurulabilir. Çoğulcu toplumdaki din öğretimi, bir dinin veya ayn dinin farklı yorumunun diğeri ile ilişkisinde en önemli amaç olan diyaloga izin veren bir bilgiyi ve diyalogdan da öte insanlığın sahip olduğu konuların ve problemlerin karşl1ıklı görüşülmesine izin vermelidir (Thompson, 1988).

Aslında toplum din öğretiminin de katkısıyla karşılıklı kültürel zenginlikten faydalanabilir ve dinî farklılı̆̆ı mümkün kılan insan hayatının anlamı hakkındaki doğruyu daha iyi anlayabilir. Yukarıda sayılan sebeplerden dolayı dinin bilgisi eğitilmiş bireyin entelektüel mirasının bir parçası olmalıdır.

\section{B. DINN ÖĞRETIMININ AMACI}

Paulo Freire eğitimin sürekli insan özgürlüğünün hizmetindeki bir uygulama olarak, dönüşüm olgusunun bir aracı olması gerektiğini ve bu dönüşümün yalnızca insanların bilinçlerinde değil, bilinçlenme sürecindeki yapılarda da gerçekleştiğini ileri sürer (Akt. Schipani, 9). Eğitimin bir parçası olan din öğretimi de acaba insan özgürlüğünün hizmetinde midir ve dönüşüm olgusunun bir aracı mıdır? Veya programın yasal bir parçası olan din öğretiminin bireyi özgür, eleştirel, yaratıcı düşünce, duygu ve davranışa yönlendirebilmesi ve dönüşümü gerçekleştirebilmesi için hangi amaçlara sahip olmas1 gerekir?

Öncelikle amaçları birbirinden farklı olan "dinî yetiştirme”, "din araştırması" ve "din öğretimi" kavramlarını birbirinden ayırmak gerekir: "Dinî yetiştirme"de amaç, doğrudan öğrencileri dine bağlı, dine teslim olacak bir şekilde yetiştirmek ve öğrencinin dinî inançlara bağlılığını ve bunlarda derinleşmesini geliştirmek iken; dini sosyal bir fenomen olarak ele alan "din araştırması"nın amacı dinin mantıksal yapısını, merkezî kavramlarını, doğru kriterlerini ve metodolojisini araştırmaktır.

"Din öğretimi”nin amacı ise sosyal bir fenomen olarak dini öğretmek ve daha objektif türden bilgiler sağlamanın ötesinde öğrencilerin hem zekâlarını hem de kişiliklerini geliştirmektir. Böylece din öğretimi daha sınırlı ve daha özel amaçlara sahip olan din araştırmasının ötesine geçer ve onu kuşatır. Birçok kişi tarafından din öğretiminin amacı din anlayışını geliştirmek olarak kabul edilir, bu başkasını kendi dinine çekmek veya mezhepsel ilgilerden farklıdır (Iheoma, 1997).

Michael Grimmitt'in "dini öğrenme”, “din hakkında öğrenme” ve "dinden öğrenme" şeklinde yaptığı sınıflandırmadaki amaçlar da yukarıdakine benzemektedir. Örneğin, "dini öğrenme"nin amacı dine inanan öğrenciler yetiştirmek, dini inancı ve eylemleri arttırmak iken; bazen 
karşılaştırmalı din eğitimi olarak da adlandırılan ve antropolojiye dayandırılan "din hakkında öğrenme"nin amacı ise bir dinin esaslarını benimsetmeye yönelik olmayan din eğitimi yaratma isteğidir. Betimsel, tarihî ve eleştirel özelliklere sahip olan bu yaklaşımda kutsal metin dinî bir kitap olarak değil, ortak inanca sahip belli bir topluluğun kitabı olarak, dinî olmayan farklı bir açıdan öğretilir. Öğrenci ile dinî içerik arasındaki mesafenin korunduğu "dinden öğrenme"nin amacı da öğrenenlerin ahlâkî ve manevî gelişimlerine katkıda bulunularak onların sosyalleşmelerine yardımcı olmaktır. "Dini öğrenme" ve "din hakkında öğrenme" bilimsel din çalışmalarıyla yönlendirilirken, "dinden öğrenme" eğitimsel bir disiplini oluşturduğundan dünyadaki birçok profesyonel din eğitimcisi tarafından destek görmektedir (Hull, 2003: 43-45).

Öğrencilerin kişisel gelişimine katkıda bulunan, onlara özgür, eleştirel ve yaratıcı bir tutum için açılım kazandıran din öğretimi veya dinden öğrenme şüphesiz dinî yetiştirme veya inanç aşılamadan (indoctrination) farklıdır. Yaratıcılığı ve özgürlüğü destekleyen bu yaklaşımlar insanların ilk çatışmaları (ergenlik vb.) ve araştırmaları ile bağlantılı olarak keşfetmelere yol açar. Bu, yaratıcı paradigmada sezgi ve iç görü ile karakterize edilen bir harekettir, iç görü ve sezgiler sayesinde gizli varsayımlar ve tutarsızlıklar yüksek oranda fark edilebilir. Özgür ve yaratıcı din öğretimi bilinçlendirme sürecinde ortaya çıkan değer ve güven, sezgi ve iç görülerine olan eğilimi besler, güçlendirir ve aynı zamanda, yeni farkında oluşlardan öğrenmek ve bunları toplumda paylaşmak için öğrenciyi yüreklendirir (Schipani). Dinî yetiştirme veya inanç aşlama ise sorgulama ve eleştirel yaklaşıma izin vermeden telkin vb. yollar ile bir dinin ilkelerini benimsetme ve bunlara alıştırmadır.

Din öğretimi inanç aşılama veya dinî yetiştirme ile karıştırıldığında problem olur, çünkü bunların amaçları farklı olduğundan ve rasyonel olmayan yöntemlerin kullanımını kapsadığından bunlarda diğerini ötekileştirmeden bilgilenme ve değerlendirme yerine ilkelere alıştırma vardır. İnanç aşılayan kişi kendi amaçlarının başarısı için insana araç olarak davrandığından inanç aşılama tartışmasına katılan bütün katılımcıların öğrencilerin kişisel gelişimi ile ilgili endişeleri vardır. Etik ilkelerin gözetildiği bir toplumda başka insanların haklarına ve özgürlüklerine saygı esas olduğundan onlar araç olarak görülmez (Iheoma, 1997). Böyle bir yaklaşımın temel alındığı eğitim anlayışında da bireyin otonomluğu ve özgürlügünün geliştirilmesi öncelikli hedefler arasında yer alır. Sosyal etkileşimde ahlak ise insanlara araç olmaktan öte amaç olarak davranmayı gerektirir, çünkü bu onların kişisel özgürlüklerine ve özerkliklerine saygıdır. Gardner'e göre, sekülarist yaklaşımda dini inançları aşılamaktan kaçınmak 
her öğretmenin ahlakî bir sorumluluğudur. Yukarıda da vurgulandığı gibi din öğretiminin eğitsel amaçları başkasını kendi dinine çekmek veya mezhepsel ilgilerden farklı olmalıdır (Akt. Iheoma, 1997: 78). Eğer öğrenciler inançlarını rasyonel evrime ve değerlendirmeye tâbi tutmazlarsa inanç aşılama olur (Iheoma, 1997).

Gardner'e göre bir çocuk ne kadar çok aş1lanmış olursa, mantıksal açıdan onun inançlarını değerlendirmesi o kadar zor olduğundan bir çocuğa derin bir şekilde inanç aşılaması yapılması özgür ideallerin başarılmasını tehdit eder (Gardner, 2004). Bazı filozoflar dine teslim olmayı ögretmede hem kişisel otonominin hem de açık fikirli olma tutumunun zarar görmesi gibi iki sorunun ortaya çıkabileceğini ileri sürerler. Bir başka deyişle dine teslim olma otonominin gelişimi ve eğitimde açık fikirlilik ile uyuşmaz, özel dinî inançlar rasyonel otonominin özgür gelişimini bozabilir (Iheoma, 1997).

Rasyonel girişimleri içeren iki unsur uyma-uyum ve eleştiridir, öğretilenler kabul edilen bazı fikirlere uyarken, ilgili her çeşit eleştirel düşünceye de maruz kalırlar. Eleştirel düşünce için gerekli olan açık fikirliliği korumanın tek yolu tarafsızlıktır, çeşitli dinî inançlar ve pratikler karşısında açık fikirliliğin korunması nötr olunmasına bağlıdır. Dinî yetiştirme veya inanç aşılama ise kapalı fikirliliğe yol açar (Iheoma, 1997). Açık fikirliliğin yanı sıra, bireysel bir değerlendirme olan nitelikli şüphe de telkinden veya didaktik öğretmeden daha uygundur. Din öğretiminde açıklık ve dürüstlük olabildiği kadar desteklenmeli ve şüphecilik ortadan kaldırılmamalıdır (Gardner, 2004).

Gardner, dinî yetiştirmenin rasyonel otonominin gelişmesine engel olan belli bir inanç sistemine teslim olmaya yol açacağı gerekçesiyle rasyonel özerkliğin gelişmesi için çocuğun nötr olarak yetiştirildikten sonra inancını kendisinin seçmesine imkân verilmesi gerektiği düşüncesini benimser. Fakat Iheoma inanç konusunda özgür karar verebilmek için Gardner'in ileri sürdüğü görüşte problem olduğunu düşünür. Iheoma'ya göre, Gardner'deki çıkmaz tartışmaya ihtiyaç duyulan temel inançların veya inanç çerçevelerinin ve inanç sistemlerinin öğretiminin yok edilmesidir. Herhangi bir konunun rasyonel tartışması için doğru değerlendirmelerin yapılabildiği bazı inanç çerçevelerinin sürekli kabulünü varsaymak gerekir (Iheoma, 1997). Çünkü böyle bir çerçeve öğrencinin çevresinden edindiği bazı bilgilerin yanlışlığını görmesine yardımcı olabilir. Ülkemizde örgün ve yaygın eğitim kurumlarında gerçekleştirilen din öğretiminin öğrenme alanlarının belki Iheoma'nın inanç çerçevesi kavramını karşıladığı söylenebilir. 
Din öğretiminin amaçlarından biri de hem bireyin kendi gelişim ve sorunlarına hem de toplumsal gelişim ve sorunlara duyarlılığ kazandırmaktır (Schipani, yıl yok). Din öğretiminin gerçekleştirmek istediği, bilișsel yeteneklerin gelişimini sağlarken, özgeci istekleri de geliștirerek vicdan gelişimini sağlayıp, bencil istekler üzerinde bir kontrol mekanizması oluşturmaktır. Duyuşsal alanın sağlıklı gelişmesine imkân tanındığında insan kendinden başkalarına, doğaya ve diğer varlıklara karşı duyarlı hale gelir. Duyarlılık ahlâkî ve estetik olmak üzere iki alanda gerçekleşir; ahlâkî duyarlılıktaki ilk adım, iyiliğin farkına varma, bir sonraki adım ise, iyiliği yapmadır. Estetik duyarlılıktaki birinci adım, güzelliği fark etme, ikinci adım ise, sanat eseri meydana getirme. İlk adımda olguyu fark etme varken, ikinci adımda bu duyarlılı̆̆ın davranışa dönüşmesi söz konusudur, önce duygulanma olur, daha sonra davranışlar ortaya çıkar. Üstün isteklerin gelişmesi, insanın sosyalleşmesi, çevresine karşı duyarlı olması, kendisinin dışındakileri fark ederek önemsemesi, ilişkilerindeki sınırları kendisinin belirlemesi ve o sınırları koruması anlamına gelir.

Din öğretiminin genel amaçlarını, içinde yer alan diğer maddelerin yanı sıra, (Bkz. T.C. Milli Eğitim Bakanlığı Din Öğretimi Genel Müdürlüğü İlköğretim Din Kültürü ve Ahlak Bilgisi Dersi $(4,5,6,7$ ve 8. Sinıflar) Öğretim Programı ve Kılavuzu, Ankara, 2006, s. 11-12) özetle şu şekilde sıralamak mümkündür:

Öğrencilere sorgulayıcı, eleştirel, özgür ve yaratıcı bir tutum kazandırmak. (Öğrenciler kazandıkları bu tutum ile kültürde var olan öğrenilmiş bilgileri ve ayetlerin farklı yorumlarını tekrar gözden geçirebilirler.)

Onların kişisel gelişimlerine katkı sağlamak.

Kültürel bir miras olarak toplumda yaşanılan dinler ve diğer dünya dinleri ve geleneklerini tanıtmak, bilgilendirmek.

Toplumun sahip olduğu ahlâkî değerlerle ilgilenilmesini sağlamak.

Farklı inanç ve ahlâkî değerlere sahip insanları anlamalarına yardımcı olmak ve diyalog aracıllğı ile bunlara karşı saygı ve anlayışı geliştirerek toplumsal ve dünya barışına katkıda bulunmak.

\section{DİN ÖĞRETIMININ İÇERIĞİ}

Din öğretiminin can alıcı sorusu "Din öğretimi gerçekten ne ile ilgilidir?" sorusudur. Alıcı durumundakilere din olarak neyin verilmesi gerekir? Din öğretimi içeriği olarak sunulanlar alıcıların talebini ve ihtiyacını karşılamakta mıdır? Ve onların bilişsel, duyuşsal, psikomotor ve kültürel gelişmişlik düzeylerine uygun mudur? Din öğretimi programı alıcıların 
potansiyel güçlerini geliştirmeye yönelik midir? Yoksa hayattan kopuk, hayata geçirilemeyen, dinamik olmayan bilgilerle kafalar doldurulmakta mıdır? Veya din bir baskı aracı olarak kullanılıp yürekler sindirilerek silik kişilikli bireyler mi yetiştirilmektedir? Bir başka deyişle bireyin özgüveninin gelişimi engellenerek özgürleşmesinin önü kapanmakta mıdır?

"Din öğretiminin ne ile ilgili olması gerektiği" sorusunun yanıtı özetle "belli bir dinin mirasını aktarmaktan daha fazla bir şey olmalı" şeklinde olması gerekir. O öğrenmedir, yaşamdır ve bütün dünyayı kuşatana kadar devamlı gelişen toplumlarla ilişki içerisinde olmak zorunda olan bir toplumdaki gelişmedir. (Thompson, 1988: 19).

İçerik bireyin kendini uydurmak zorunda olduğu bir kurallar bütünü olmak yerine bireyin ve toplumun gelişimine katk1 sağlayan, var oluşu yorumlayan ve hayatın problem çözücü kaynaklarından biri olarak iş görmek durumundadır. İçerikteki hareket noktası metin değil öğrenen olmalıdır ve dinî metin insanlığın birikimi ve başarılarının ışığında yeniden anlaşılmalı ve öğrencinin dünyasına katılmalıdır (Selçuk, 2005: 173,174)

Farklı dinlerin öğretimlerinin doğru olarak yapılması yalnızca din öğretiminin bir parçasıdır, din öğretimi yalnızca sınıflarda ve kurslarda ele alınamayacak kadar kapsamlı hayat boyu süren bir süreçtir. Okullar, kurslar ve mabetler bu görevin bir parçasını üstlenirlerken, kolejler, üniversitelerin ilgili bölümleri ayrıca teoloji ile ilgili seminerler de din öğretiminin genişleyen alanında sorumluluğu paylaşmalıdırlar, Bütün bu kurumların yanı sıra aile ve toplum da eğitim işinde önemli katılımcılardır (Thompson, 1988).

Hayattan kopuk, hayata geçirilemeyen ve dinamik olmayan bilgilerle kafaların doldurulma ve dinin baskı aracı olarak kullanılma endişesi din öğretiminin en önemli sorunlarındandır, bu ve benzeri sorunların giderilmesi için bilimsel bir yaklaşım ile çaba harcanmadığında ise olumsuz sonuçlar ile karşılaşılması kaçınılmaz olur. Kutsal metnin donuk bir şekilde modern çağa aktarımı, dolayısıyla onun çağın gerisinde bırakılması; bu aktarılan donmuş, kalıplaşmış içeriği kabul eden zihinlerin de donuklaşmasına sebep olunarak, yaratıcılıklarının öldürülmesi ve otonom, otantik, rasyonel ve eleştirel düşüncenin önünün kesilmesi bu olumsuz sonuçlara birkaç örnek olarak gösterilebilir.

20. yüzyılda J. J. Rousseau'nun çocuğun bizzat deneyerek öğrenmesini isteyen 'deneysel doğacılık' görüşü geliştirilerek pragmatik eğitim felsefesi oluşturulmuştur. $\mathrm{Bu}$, çocuğun incelenmesine, onun özelliklerine uygun eğitim-öğretimin uygulanmasına ve yeni, gerçekçi bir eğitim felsefesi doğmasına yol açmıştır. $\mathrm{Bu}$ eğitim felsefesinde bilimsel yaklaşım ön 
plandadır; deney, uygulama ve bunları zihin süzgecinden geçirme, eğitimöğretimde başlıca hareket noktası olmuştur.

Schipani'nin eğitim programı da bireyin ve toplumun özelliklerinin dikkate alınmasını ister, buna göre din öğretimi programı şunları içermelidir:

1. Kişisel gelişim, kişisel olgunlaşma ve toplumsal değişim.

2. Günün çevreleyen gündemi, bir başka deyişle günün sosyal, politik ve kültürel eğilimleri.

3. Hem ibadet yerlerinde hem de toplumdaki din ile ilgili farkl etkinliklere duyarlı bir şekilde yönelerek yaratıcı ve liberal hareket içinde kutsal metnin yorumla incelenmesi.

4. Bireyin kendi gündemi (Schipani, 190, 193).

Dinler hakkındaki bazı gerçeklerin öğrenilmesinin önemli olduğu düşünüldüğünden, din öğretimi programının bilişsel içeriği öncelikle bu gerçeklerin öğrenilmesini merkeze alır. Bu gerçeklerden hayatın, doğanın ve evrenin hikmetlerine ulaşılabilir mi? Saygı ve işbirliği konusunda bu gerçeklerin bilgisi nasil rol oynar? Şüphesiz bu gerçeklerin bilgisine sahip olunmadığında ilgisizliğin, korkunun, şüphenin, önyargının hatta nefretin yolu açılır (Thompson, 1988: 30).

Din öğretiminde bilişsel içeriğin yanında duyuşsal parçanın gücü de önceki zaman dilimine göre daha büyük bir açılım kazanmaktadır. Mabetlerin rahatsızlık vermeyen 1şıklandırmaları, mistik atmosferleri ile uyumlu sanatı; estetiği yansıtan mimari yapıları ve süslemeleri, kiliselerin çiçekler, tütsüler, heykeller ve azizlerin resimleri ile işlenmiş sunakları ve mumları duyuşsal öğelerdendir. Yahudiler ve Müslümanlar güzel camiiler, sinagoglar ve mabetlere sahip olmalarına rağmen, sadeliklerinin içinde huşunun artan gücünü hissettirmek için heykellerden, ikonalardan, sunaklardan kaçınmışlardır (Thompson, 1988).

İtirazların olmasına rağmen din, tarihî olarak kültürel zenginliklerin bazıları ve musiki, sanat ve edebiyat gibi sanatsal etkinliklerle de yakından ilişkilidir. Din öğretiminde duyuşsalın önemi tartışma götürmediğinden, fakat çekişme ve yanlış anlaşılmalardan da kaçınmak için, bu gibi deneyimlerin planlanmasında hassasiyet gösterilmesi gerekir. Güzelliğin, huşunun veya diğer dinlere saygının, bireylerin bütünlüğünün ve onların belirli dinî geleneklerine bağl1lıklarının göz önünde bulundurulduğu içerikte hangi tür deneyimler ve hangi tür donanımlara sahip din eğitimcileri bulunmalıdır? Deneyimlerin hangi çeşidi arkadaşlık, anlayış, farklılıklara saygı ve işbirliği için istek duygusunun artmasına yardım edebilir? Dinî olanla tamamen kültürel olanı birbirinden ayırmak önemli midir? Mümkün müdür? Eğer müzik, dans ve sanat gibi yönleriyle kültürel olan dinî olandan ayrilırsa ikisi de bozulur mu? (Thompson, 1988). 
Din öğretimi programının bilişsel ve duyuşsal boyutundan sonra son olarak içeriğin psikomotor yönü ile diğer dinlere saygı konusunda artan birçok sorular vardır. Hangi davranışlar din açısından arzu edilir? Dinî perspektif, toplumda odak noktasına sahip olan bizim araştırmalarımız ve davranışlarımız mıdır? $\mathrm{Bu}$ çalışmalar kapsamlı olmak ve hayatı zenginleştirmek için midir? Yaşantıları belirlemede yardımcı olacak olan bu sorular nasıl cevaplandırılabilir? Hem bu yöndeki davranışlar hem de bu yaşantılardan etkilenecek öğrencilerin faaliyetlerini yüreklendirecek olan ümit nasıl yaratılabilir? Öğrenenlerin teolojisi beklenilen eylemler için uygun mudur? Diğer dinlerin üyeleri, vurgulanan arkadaşlık, ibadet yerlerini ziyaret, yoğun araştırma veya bir toplum projesini geliştirmede beraber çalışma konusunda genellikle şüphecidirler. Engeli ortadan kaldırmak için büyük bir istek olsa da bir engel vardır ve onun bertaraf edilmesi zordur (Thompson, 1988).

Din öğretiminde aktarıcı durumunda olan aracı zihniyetlerin temel kaynakları kendi donanımlarına paralel olarak anlamaları ve yorumlamaları da bu süreçte farklı bilişsel ve duyuşsal sonuçların yanında değişik yaşantıların da ortaya çıkmasına sebep olmuştur. Ayrıca alıcı durumunda olanların bilişsel ve duyuşsal gelişmişlik düzeylerinin, kültürel donanımlarının eşit olmaması da farklı algılamalara, benimsemelere ve tutumlara yol açar; bu durum aynı zamanda bu alanda farklı içeriklere sahip çeşitli eserlerin üretilmesine de sebep olmuştur.

Yukarıda açıklanan programın üç bölümünün yanında, içeriği planlanmayan, çoğu kez negatif olan "gizli müfredat" diye isimlendirilen program da görmemezlikten gelinmemelidir. Hıristiyan kiliselerinde onların çocuklarının ve gençlerinin eğitiminde kullanılan programdaki Yahudi aleyhtarlığını gösteren ifadeler ve ima edilen fikirler gizli müfredata bir örnek olarak gösterilebilir. Aslında program hazırlanırken kasıtlı olarak Yahudi aleyhtarlığı ile ilgili konular programa katılmamıştır, fakat seçilen konular bu ayrillğ 1 vurgular. 1950'li yıllarda Amerikan Yahudi Komitesi tarafından başlatılan projelerin sırasının dizilişi, Protestan, Yahudi ve Katolik eğitimciler tarafindan üretilen öğretim materyallerinde konu edinen grup arası ilişkileri göstermeyi amaçlar. Protestan materyallerinde yaklaşık 120.000 ders konusunu araştıran Yale üniversitesinden Bernhard Olson rahatsızlık verici, yüzdesi yüksek Yahudi aleyhtarlığı ile ilgili ifadeleri bulur. 1972'de benzer bir çalışmayı yöneten Gerald Strober Protestan dinî metinlerini araştırır ve bir önceki çalışmanın sonuçlarında bir düzelme olmadığını görür (Thompson, 1988: 32-33). 
Sonuç olarak, zamana ve mekâna duyarlı olması gereken program genellikle değerin bireysel sistemine dayanmal, bireylerde çeşitli etkenlere bağlı olarak gelişim, değişim ve dönüşüm olabileceği de dikkate alınarak zaman ve mekândaki değişikliğe göre, program pratiklerinde de değişiklik yapılmalıdır. Mümkün olabildiği kadar öğrencilerin farklı ilgilerini ve tercihlerini dikkate alması ve fursat eşitliğini koruması istenilen program daha az yetenekli olarak isimlendirilen öğrencilerin de bir kenara atılmalarını engellemelidir. Ayrıca program için yalnızca konuları belirleme yeterli değildir, bu belirlemenin gerekçeleri de gösterilmelidir (Woods \& Barrow, 1975). Çok yönlü hazırlanan din öğretimi içeriği, gerçek hayat mücadeleleri, insanların çatışmaları onların ihtiyaçları, ilgileri, özlemleri ve hayallerine odaklanırsa işlevselliği sağlanabilir (Schipani) Din öğretimi programı öğretmenlere öğrencilerin kendilerini yansıtacakları konuları öğrencilerle beraber seçmelerine izin vermeli ve güncel konuların da ele alınabilmesine elverişli olacak şekilde esnek olmalıdır. Schipani (50)'ye göre, insan ilişkilerinin tarih ve doğasının bütün alanları potansiyel olarak din öğretiminin konusudur.

\section{DIN ÖĞRETIMININ YÖNTEMI}

Din öğretiminin amaçlarında gerçekleşen değişiklik onun metodolojisinin de değişmesine yol açmıştır. Kutsal metnin içyüzünü kavrama ve mesajını anlamanın onda geçen olaylar hakkında bilgilenmekten daha önemli olduğu kabul görmektedir (Iheoma, 1997: 56). Öğrencilere anlamlı gelecek bir din ögretimine olan ihtiyacın fark edilmesi ve bu farkındalığın giderek büyümesi sayesinde yeni amaç, içerik ve yöntem arayışları ile ilgili çeşitli çalışmalar başlamıştır.

Din öğretiminin geçirdiği tarihî sürece bakıldığında başlangıçtaki özgür ve eleştirel düşünceye imkân tanıyan dinamik anlayışın yerini zamanla geleneksel bilgi aktarımına, kutsal metinlerin ezberlenmesine bıraktığı görülür. "İlmin yalnızca bilgi aktarımı olarak değerlendirilmediği, sınırsız bir fikir özgürlüğü ve eleştirinin yer aldığı Osmanlı öncesi İslâm dünyasının mütekaddimîn (Gazzâlî öncesi düşünce hareketlerinin olduğu dönem) dönemi üretken düşünce, bilim hayatı ile dikkat çekmiş ve bu dönemde önemli eserler verilmiştir" (Kaya, 1999,150) .

İlmin yalnızca bilgi aktarımı olarak anlaşıldığ 1 durumlarda ise karşıt görüşleri belirtme, eleştiren, üreten zihin, yerini aktarılanları sorgulamadan kabul eden, pasif, üretemeyen zihinlere, ilmî donukluğa bırakmış ve dolayısıyla ilerlemenin ve gelişmenin önü kapanmıştır. Kuruluşlarından itibaren devletin yükselişine paralel olarak gelişme gösteren, toplumun bilginlerini, din görevlilerini ve bürokratlarını yetiştirme görevini başarı ile 
yerine getiren Osmanlı medreseleri, devletin duraklamaya başladığı XVIII. yüzyıl başından itibaren batılılaşma hareketi ile başlayan gelişmelere, değişen dünya düzenine kendini yenileyip geliştirerek ayak uyduramadığından dolayı kapanmıştır (Atay, 1983; Tekeli-İlkin, 1993).

Tanzimat döneminde Avrupa ile ilişkilerin artmasından sonra yöntemsizlik eğitimdeki geriliğin sebebi olarak görülmüş ve aydınlar 'eğitim-öğretimde yeni yöntem' konusunu gündeme getirmişlerdir. Bu düşünceden hareketle yeni yöntem bilen öğretmen yetiştirilmesi, mevcut öğretmenlerin hizmet içi eğitimle yöntem bakımından desteklenmesi girişimlerinde bulunulmuş ve yeni yöntemle işleyen örnek okullar açılarak bunların yaygınlaştııılmasına çalışılmıştır. Hatta yeni yöntemin okullarda uygulanması ile çocukların dinî görevlerini daha kolay öğrenebilecekleri bildirilmiştir (Parladır, 1984).

Dış dünyadaki değiş̧meler ile düşünce, bakış açısındaki değişmeler ve hayat anlayışındaki dönüşümler arasında paralellik olduğundan, toplumsal alandaki değişme ve gelişmeler din öğretimine de yansımıştır. Örneğin, "Birleştirici Model", "Çoğulcu Model", "Mezhebe Dayalı Din Dersi", "Mezhepler Üstü Din Dersi", "Çoğulcu Model", "Din Öğretimine Fenomenolojik Yaklaşım" gibi yeni din öğretimi modelleri din eğitimcilerinin değişen ve gelişen dünya şartlarında mevcut uygulamaları yetersiz bularak yöneldikleri arayışların sonucu ortaya koydukları çözümlerden bazılarıdır.

Günümüzde din öğretimi yöntemlerinde görülen sorunların başında genellikle geleneksel olan anlatma (takrir) yönteminin kullanılması gelir. Din eğitimcisinin aktif, dinleyici durumunda olan alıcıların pasif olduğu bu yöntemde pasif alıcı durumunda olanların dikkatlerinin sürekli canlı tutulmas1, öğrencilerin ve dinleyicilerin derse katılmas1 mümkün olmadığından geçici duygusal heyecanlanmalar olsa bile tam anlamıla kalıcı bir öğrenme gerçekleşemez. Pasif olan öğrenci sıkılır ve ilgisi ders dışına kayabilir ve vericinin, aktarıcının kullandığı kavramlar alıcı tarafından doğru olarak algılanmadığı durumlarda da iletişim bozukluğu olur.

Anlatma yönteminin kullanıldığı eğitim, öğrenci merkezli, dinamik bir eğitim değil, öğretmen merkezli bir eğitimdir. Sosyolojinin ve tarih felsefesinin öncülerinden kabul edilen 14. yüzyılın sonu ve 15 . yüzyılın başında, geleneksel eğitim-öğretim yöntemlerinin yaygın olarak kullanıldığı dönemde, yaşayan İbn Haldun o dönemde bile bu yöntemi eğitim-öğretimde duyuşsal ürünlerin oluşmasında etkili bir telkin aracı olarak görmekle beraber, ezberciliğe yol açması, çok vakit alması ve konuşma melekesini geliştirmemesi gibi sakıncalarına dikkat çeker (Âşık Ev, 2007). 
Öğretmen merkezli eğitimde öğrencilerin, alıcının zekâ düzeyleri, ilgi ve isteklerinin farklılığ 1 göz önünde bulundurulmadan dıștan, belki dayatmacı bir eğitimin uygulanması söz konusudur. Dayatmacı eğitimde ise zorlama ve korku vardır. Dışardan gerçekleştirilen eğitim sonucunda, sorgulamadan alan, kabul eden, taklitçi, şekilci, manevra yeteneği gelişmeyen ve esnek beyinlere sahip olmayan öğrenciler yetişir. Verilenlerin, üzerinde düşünülmemesi gereken şeyler olduğu da vurgulandığında, öğrenciler sebep-sonuç ilişkilerini göz önünde bulundurmadan, kaderci bir yaklaşımla duyduklarını sorgulamadan olduğu gibi alır ve bilimsel gelişmeleri izleyen, olaylara nesnel yaklaşabilen, sorunlara rasyonel çözümler bulabilen zihinlerin gelişmesi engellenir.

Oysa eğitim, özgür iradeli bireyler yetiştirmeli ve çocuğu alışkanlıkların zulmünden kurtarmalıdır. Eğitimi yaşama hazırlık değil yaşamın kendisi olarak kabul eden John Dewey'e (1859-1952) göre eğitim, çocuğun günlük yaşama etkin bir biçimde uyum sağlamasına katkıda bulunduğu oranda değerlidir, bu da çocuğun her şeyin merkezine konması ile gerçekleşir (Dewey 1996). J. Dewey ve 20. yy. eğitimcilerine göre, eğitimde çocuğun ilgisi esastır, bu ilgi doğal olarak yoksa yapay olarak yaratılmalıdır. Öğrenme, öğretim ve eğitimde temel olan, öğrencilerin yaşantı kazanmalarıdır, yaşantı kazandırmada öğrencinin temel ihtiyaç ve güdülerinden yararlanılır. En iyi yöntemler gözlem, deney ve sorun çözmedir. Öğretimde beş duyuya hitap eden araç ve gereçlerden yararlanılır (Dewey 1996). Önemli olan, kural ezberlemek değil, çocuğun kurallara bizzat kendisinin sahip olmasıdır.

J. Dewey'e göre eğitimin amacı; çocuğa ne düşüneceğini değil, düşünmeyi öğretmektir (Dewey 1996: 180). 'Problem çözme yöntemi' ve 'demokratik eğitim ilkeleri' bu amacın gerçekleştirilmesi sırasında eğitimcinin kullanacağı esaslardır. Öğrenci merkezli eğitim dışarıdan içe doğru değil, içten dışa doğru bir eğitimdir, çocuğun ilgileri, istekleri, kapasitesi ve öğrenciler arasındaki fark göz önünde bulundurulur; çocuklar büyüklerden farklı oldukları gibi birbirlerinden de farklıdırlar. Çocuk bilgisinden yola çıkarak çocuğun tanınması esastır, çocuk psikolojisine dayanılarak oluşturulan şartlarda çocuğun zevk alarak öğrenmesi sağlanır.

Din öğretiminin tarihi sürecinde ezbere fazlasıyla yer verilmesi de islah çalışmaları ile düzeltilmeye çalışılan bir başka sorundur. Tanzimat döneminde eğitim alanında yapılan ıslah çalışmalarında çıkan bir genelgede, çocuğa gücünün üzerinde ders verip ezberletme yasaklanarak ezber yöntemi hafifletilmiştir (Parladır, 1984). Geleneksel eğitimde takip edilen ezbere dayanan yöntemin belki bazı zihinsel yetilerin gelişimini başlattığı ileri sürülse de, rasyonel düşünme, çözümleme, eleştiri vb. zihinsel yetilerin gelişimini de engellediği düşünülebilir. 
Din öğretimi sürecinde öğrencilere sorular sorularak onların uyanık olmaları, meraklarının canlı tutulması, konu üzerinde düşünmeleri sağlanırken, öğrenciler tarafından sorulan sorular yanıtsız bırakılmamalı ve soru sormalarına engel olunmamalıdır. Soru sormaları engellendiğinde veya soruları yanıtsız bırakıldığında öğrencilerin öğrenme istekleri kırılacağı gibi öğrenmeleri, almaları durur, yeteneklerinin üstü kapanarak gelişmesi engellenir. Din öğretiminde soru sorulmasının günah, yasak diyerek engellenmesi ve dinî konuların birer tabu haline getirilerek erişilmesi mümkün olmayan uzaklıklara yerleştirilmesi sonucunda sorgulamadan alan, merak etmeyen, yeni şeyler öğrenmeye çaba göstermeyen, pasif bireyler ve içselleşmeyen, yüzeysel, şekilci bir dindarlık tipi ortaya çıkar.

Fransız Aydınlanması düşünürleri mevcut eğitim kurumlarındaki sorucevap yöntemini kullanan dinî eğitimin ilerletici bir bilimsel yaklaşımı öğretmekten ziyade ortaçağdaki zihinsel durgunluğu empoze ettiğini ileri sürerek, bu eğitim kurumlarını zihinleri tutsak etmekle suçlayıp eleştirmişlerdir. Öğretimde soru-cevap yönteminin diğer yöntemlerle birlikte, örneğin diyalog sürecinde, öğrencinin motive edilmesi ve aktif hale getirilmesi için bir yardımcı yöntem olarak kullanılması daha uygundur.

Diyaloga imkân tanıyan din öğretimi dinleme ve konuşma sürecini açar ve dinlemeye ve konuşmaya açıklı̆̆ geliştirir. Kişisel deneyimleri, hikâyeleri ve görüşleri paylaşmayı içeren bu diyalog süreci öğretmenler ve öğrenciler için, uyanıklık, farkında oluş, eşiğini yükseltirken dönüştürme, zihinsel, moral ve inanç gelişimi ile ilgili yaşantıların yardımı ile hem öğretmenleri hem de öğrencileri özgürleştirici ve yetki vericidir. Bu aynı zamanda ortak ilgi ve toplum binasını da güçlendirebilir (Schipani).

Din öğretimi ilgili olan üretici konuların tartışılmasını kolaylaştıracak olan basılı materyaller, grafikler, bilgisayar, projeksiyon, vb. din öğretimini kolaylaştırıcı, zevkli ve kalıcı hale getirici öğretim teknolojileri; sunumlar, drama, vb. aktiviteler de yöntemler arasında sayılabilir. Özetle, öğretmenlerden pasif bir gözlemci olmaktan öte, öğrenme sürecinde, özellikle öğrencilerin dönüştürme becerilerini arttırmak için onların yaratıcılıklarını geliştirmelerini sağlayacak yöntemler kullanmaları beklenir (Schipani).

Din öğretiminde alıcının bilişsel ve duyuşsal güçlerinin devreden çıkartılarak, psikolojik baskı kullanıp, inanç aşılamaya çalışılarak öğretme yerine, bunların devreye sokularak işletildiği ve geliştirildiği yöntemlerin kullanılması, bir geliştirme süreci olan eğitimin yetenekleri baskı altına almadan, ileriye dönük olarak dengeli bir şekilde geliştirerek davranışa dönüştürmek hedefi ile de örtüşür (Schipani). 
Son olarak, din öğretiminde kutsal metnin geldiği tarihî bağlamın bilinmesini de içeren hermeneutik yöntemin günün değişen ve gelişen şartları ve ihtiyaçlarına göre kutsal metnin doğru anlaşılması ve yorumlanabilmesi için gerekli olan yeniden okumaları bize kazandırabileceğini söylemek yanlış olmaz. Luis Segundo'nun metodolojisine göre, teolojinin liberalleştirilmesi günümüzün değişen gerçeklerine göre dinî metinlerin yorumlanmasını ilgilendiren hermeneutiki içermektedir. $O$ hermeneutiki günümüzün değişen ya da dikte edilen gerçeklerinin 1şığında kutsal metnin yorumlarımızdaki sürekli bir şekilde değişimi olarak tanımlar; bir diğer deyişle kutsal metnin tarihsel bağlam ile şu anki duruma göre karşl1ıklı etkileşimini içerir. Bu yaklaşım öncelikle gerçekliğin görülmesi hakkında ideolojik şüpheye yol açar; daha sonra bu ideolojik şüphenin teolojik şüpheye dönüşmesi sağlanır, böylece geleneksel ve şimdiki kutsal metinlerin yorumlanmasından şüphe duyulması sağlanır; bu da yeni hermeneuetiğe varılmasını sağlar ki bu, yeni düzen hakkında. kutsal metinlerin yeniden yorumlanma yollarıdır. Kısaca, ideolojik, teolojik ve yorumsal şüpheye sahip olunur ve bu üç aktif şüphe kutsal metnin yorumlanmasinda yeni okumalar-anlamalar- elde edilmesine sebep olur (Schipani).

\section{SONUÇ ve DEĞERLENDİRME}

Bütün bir insan ve toplum hayatına yayılabilen, teknikten dine kadar oldukça geniş ve değişken bir görünüm arz eden değerlerde pluralizm esastır, bir başka ifade ile değerler de gelişim ve değişimden etkilenerek dönüşüme uğrayabilmektedir. "Ancak bu değişim ve dönüşümde değer yok olmamakta, sürekli olarak âdeta yeniden organize olmakta ve idrakimize yeni şekillerde çarpmaktadır. Bunun için değerler, bireylere sadece anlatılmamalı, kuru kuruya verilmemeli, bütün boyutlarıyla ele alınmalı, değer alanlarının farklılığ 1 ve bağlı olduğu şartlar göz ard1 edilmemelidir (Tozlu, 2003: 79-80).

Toplumun kimliğini ve varlığını korumak ve sonraki neslin hayatta kalmasını sağlamak gibi iki önemli amaca sahip olan sosyalizasyon aracılığ ile bir toplum varlığını devam ettirmeye çabalarken, çevresindeki değişikliklere uyum sağlamaya da çalışır (Iheoma, 1997). Şüphesiz sosyalizasyon aracilığı ile gerçekleşen bu uyum sağlama sürecinde din ögretimi de aktif bir rol üstlenmektedir. Bu nedenle din bilimleri (ilahiyat) ile eğitim bilimlerinin işbirliğinin ürünü olarak ortaya çıkmış olan din eğitim bilimine (din pedagojisine) ülkemizde çok fazla önem verilmeli ve bu alanın diğer insan bilimleriyle işbirliği içinde olmasına dikkat edilmelidir. Bu bilim deneysel araştırma verilerinin 1şığında iş görmeli ve yaşamı, yaşamsal değerleri ve beklentileri hesaba katarak kendini sürekli yenilemelidir. Aksi halde yaşamdan kopuk bir din eğitimi ağır/dogmatik havasından kurtulamayarak hiç de ilgi çekici bir nitelik kazanamaz (Kale, 1999: 28). 
Dinî inançlara bağlılık hem inancı modern çağın gereklerine ve ihtiyaçlarına göre güncellemekten sakınma hem de başkasının inançları veya alternatif inançlar konusunda kapalı fikirli olmak anlamına gelmez ve açı fikirlilik ve tarafsızlık da inanç yokluğu ile eşit sayılamaz. Bir inanca bağl11ı, o inançta mümkün düzeltmeye mantıken açık fikirli olmayı engellememelidir (Iheoma, 1997). "Din insan için vardır, insan din için değil. Modern dünyada genelde bütün yaklaşımlar insan merkezli olduğundan ve insanı merkeze almayan bir değer söz konusu olamayacağından insanın fikrî kazanımlarını dikkate almayan bir dinî düzenleme insanı mutlu edemeyecektir. Bilimsel ve teknik kazanımları ve bunlara bağlı kültürel açılımları göz ardı eden bir dinî yaklaşım modern dönemin insanına hitap etmeyecektir. Modern insanı mutlu edecek bir din, gelişim ve değişimini bilime endekslemek zorundadır. Bunu başarabilmek için. "geleneksel" ve "nakilci" değil, insanın aklını ve bilincini temel alan bir "rasyonel yaklaşım"ın dinde bir yöntem olarak kabul edilmesi gerekir." (Özcan, 2007, 134-135)

Dogmatik olarak inanan ile bir yandan inanı bir yandan da sorgulayip, eleştirel tutumu ile inancını yaşadığı çağın dışında bırakmayarak sağlam temellere oturtmaya çalışanı ayırmak gerekir. Eğer bu ayrımın yapılmasına şüphe ile yaklaş1lıyorsa o zaman şu sorular üzerinde düşünülmesi kaçınılmaz görülmektedir: Din statik midir? Böyle kabul edilirse onun evrenselliği söz konusu olabilir mi? Dinin evrensel olduğunu söyleyen kutsal metinleri nasıl anlamak gerekir? Dini statik bir yapıya hapsetmek sorumluluk gerektirmez mi? Bu tür zihinsel çaba ve benzerleri "dini değiştirme" olarak algılanıyorsa insan için gönderilen dinin modern insanın ihtiyaçlarına da cevap verebilmesi nasıl sağlanacaktır? Eğer bu gereksiz olarak düşünülüyorsa, bazı bilim insanlarının doğuştan olarak kabul ettiği "Aşkın Varlığa inanma" ihtiyacını gidermek için başka arayışlar içinde olan veya dinin modern çağ ile uzlaşamayan sunum ve yorumunu görüp de ondan uzak kalmayı tercih edenlerin sorumluluğunu kim üstlenecektir? İnanç gelişiminden ne anlaşılmaktadır? Geleneksel yorumlara bağl1lık inanç gelişimini engellemez mi?

Sonuç olarak, bireyin kitle bilincini kırıp kim olduklarını ve kim olarak çağrılmak istediklerini eleștirel bir şekilde farkında olmalarını sağlayan din ögretiminden (Schipani), din ile ilgili bilgiyi yansıtma ve geleneği anlama; bireysel inançları, değerleri ve eylemleri yeniden yaratma; sosyal ve genel dünyamızı dönüştürme konularında da yardımcı olması beklenmektedir (Iheoma, 1997). 


\section{KAYNAKLAR}

Âşık Ev, H. (2007). “İbn Haldun'un Eğitim Görüşü.” Yayımlanmamış doktora tezi, Dokuz Eylül Üniversitesi Sosyal Bilimler Enstitüsü, İzmir.

Atay, H. (1983). Osmanlılarda Yüksek Din Eğitimi, İstanbul: Dergah Yayınlar1.

Ayhan, H. (1998). "İslâmiyet'in Eğitime Getirdiği Değerler", Din Eğitimi Araştırmaları Dergisi, Sayı 5.

Bilgin, B. (2001). Eğitim Bilimi Ve Din Eğitimi, Ankara, Gün Yayıncılık.

Dewey, J. (1996). Demokrasi Ve Eğitim Eğitim Felsefesine Giriş, (Çev, Tahsin Y1lmaz), İzmir: Ege Üniversitesi Basımevi.

Gardner, P. (2004). "Hand on religous upbringing", Journal of Philosophy of Edecation, 38, (1), 120-127, Blackwell Publishing.

Hull, J. M. (2003) "Demokratik Çoğulcu Toplumlarda Din Eğitimi Üzerine Genel Değerlendirmeler", (Çev. Didem Namsan), Din Öğretiminde Yeni Yöntem Arayışları Uluslar Arası Sempozyum Bildiri ve Tartışmalar 28-30 Mart 2001-İstanbul, Ankara: Milli Eğitim Basımevi.

Iheoma, E. O. (1997). The Philosophy Of Religious Education, Enugu, Nigeria: Fourth Dimension Publishers.

Kale, N. (1-3Eylül 1999). Din Kültürü ve Ahlak Bilgisi Öğretimi (Ders Kitaplarının Söylemsel ve İçeriksel Analizi), VIII.Ulusal Eğitim Bilimleri Kongresine sunulmuş bildiri, Karadeniz Teknik Üniversitesi.

Kaya, M. (1999), “Osmanlı Medreselerinde Felsefe-Kelâm Münasebetleri”, İslam Düşüncesinde Yeni Arayışlar II, İstanbul: Rağbet Yayınları.

Kirste, R. (2003). “Almanya'da Dini Çoğulculuk ve Okullarda Dinler Arası Öğretim Önerileri”, (Çev. Şerif Özdamar), Din Öğretiminde Yeni Yöntem Arayışları Uluslar Arası Sempozyum Bildiri ve Tartışmalar 2830 Mart 2001-Istanbul, Ankara: Milli Eğitim Basımevi.

Mengüşoğlu, T. (1968). Felsefeye Giriş, (3. Baskl), İstanbul: İstanbul Üniversitesi Edebiyat Fakültesi Yayınları.

Orta Öğretim Din Kültürü Ve Ahlâk Bilgisi Dersi Öğretim programı (9, 10, 11 ve 12.Sinıflar), (2005), Milli Eğitim Bakanlığı.

Özcan, H. (2007). "Modern Çağda Dinin Birey ve Toplum İçin Anlamı", Akademik Araştırmalar Dergisi, Y11 9, Sayı 32, İstanbul. 
Parladır, S. (1984). “İslam’ da Örgün Din Eğitimi.” Yayımlanmamış doktora tezi, , Dokuz Eylül Üniversitesi Sosyal Bilimler Enstitüsü, İzmir.

Schipani, D. S. (Tarih yok). Religous Education Encounters Liberation Theology, Birmingham, Alabama: Religous Education Pres.

Selçuk, M. (!997). "Din Öğretiminin Kuramsal Temelleri (Zihin Gelişimi Açısından Bir Deneme)", Din Eğitimi Araştırmaları Dergisi, 4, 151156.

Selçuk, M. (7-9 Nisan 2005). Din Öğretiminde Yeni Açılımlar, Ülkemizde Laik Eğitim Sisteminde Sosyal Bilim Olarak Din Öğretimi Kurultayı Bildiri ve Tartışmaları Sempozyumuna sunulmuş bildiri, Malatya, İnönü Üniversitesi.

T.C. Milli Eğitim Bakanlığı Din Öğretimi Genel Müdürlüğü İlköğretim Din Kültürü ve Ahlak Bilgisi Dersi $(4,5,6,7$ ve 8 . Sinıflar) Öğretim Programı ve Kilavuzu, (2006). Ankara:

Tekeli, İ. ve İlkin, S. (1993). Osmanl İmparatorluğu'nda Ĕgitim Ve Bilgi Üretim Sisteminin Oluşumu Ve Dönüşümü, Ankara: Türk Tarih Kurumu Basımevi.

Thompson, N. H. (1988), "The Challenge of Religous Pluralism”, Religous Pluralism and Religous Education (pp. 7-36 ). Birmingham, Alabama: Religous Education Pres.

Tozlu, N. (2003). Eğitim Felsefesi, Ankara: Milli Eğitim Bakanlığ Yayınlar1.

Woods, R G \& Barrow, R St C. (1975). An introduction to philosophy of education, London: Methuen and Co Ltd. 